\title{
Photosynthetic traits of freshwater lichens are consistent with the submersion conditions of their habitat
}

\author{
C. Coste ${ }^{1 *}$, E. Chauvet ${ }^{2,3}$, P. Grieu ${ }^{4}$ and T. Lamaze ${ }^{1}$ \\ 1 Université Paul Sabatier, Département Biologie et Géosciences - Centre Etude Spatiale Biosphère - UMR 5126,518 av. Edouard \\ Belin, bpi 2801, 31401 Toulouse cedex 9, France \\ 2 Université de Toulouse, UPS, INPT, EcoLab, 118 route de Narbonne, 31062 Toulouse cedex 9, France \\ 3 CNRS, EcoLab, 31062 Toulouse cedex 9, France \\ ${ }^{4}$ Université de Toulouse, INP-ENSAT, UMR 1248 AGIR (INPT-INRA), 31326 Castanet Tolosan, France
}

Received 9 September 2015; Accepted 17 February 2016

\begin{abstract}
In this study, we compared the photosynthetic performance of epilithic freshwater lichens on siliceous stream rock submerged for: more than 9 (hyper-), 6-9 (meso-) or 3-6 months (sub-hydrophilic lichens). In the dry state, neither variable fluorescence nor respiration activity could be detected. In the wet state, rates of dark respiration $\left(\mathrm{O}_{2}\right.$ uptake and $\mathrm{CO}_{2}$ production for immerged and in-air samples) were in the lower range of that reported for non-aquatic lichens. With 200 (under water) or $500 \mu \mathrm{mol}^{-\mathrm{m}^{-2}}$. $\mathrm{s}^{-1}$ photosyntheticallly active photon flux density (PPFD) (aerial), photosynthesis was positive but rates were lower than that published for non-aquatic species. Under intense PPFD (2000 $\mu \mathrm{mol} . \mathrm{m}^{-2} . \mathrm{s}^{-1}$, aerial), photosynthesis increased in sub- but became negative in hyper-hydrophilic species. After hydration, dry samples increased photosystem II (PSII) efficiency, which reached near steady state in $<6-7$ min. Hyper-hydrophilic lichen took longer than sub-hydrophilic species. A long period of desiccation (4 months) had a negative effect on subsequent PSII photochemistry of hyper- but not of sub-hydrophilic hydrated lichens. When thalli were allowed to dehydrate, all types of lichens lost PSII activity after about 15-20 min. Deactivation was faster in the hyper- than in the sub-hydrophilic species. The metabolic traits presented here are thus consistent with the ecological amplitude of the freshwater lichens studied.
\end{abstract}

Key words: Lichens / freshwater / ergosterol / photosynthetic pigments / photosystem II activity

\section{Introduction}

Lichens, with a thallus, formed by the symbiotic association of a fungus and an alga and/or cyanobacteria, are desiccation-tolerant (poikilohydric), and their water content varies drastically with that of their environment (Richardson, 1993). Lichens colonize a remarkable range of habitats with great differences in the supply and abundance of water. Only a small number of freshwater lichens live permanently submerged so they are adapted to wetting and drying cycles as experienced during diurnal and seasonal fluctuations in water availability. Their response to drying and rewetting is a key feature for survival in their habitat (Richardson, 1993). In Europe, only a few papers have been devoted to freshwater lichens (Nascimbene and Nimis, 2006). According to Santesson (1939) and Aptroop and Seaward (2003), freshwater lichens are amphibious organisms, most being actually submerged only during a

\footnotetext{
*Corresponding author: cloter@wanadoo.fr
}

part of the year. Not only the rock substrate but also the duration of thallus flooding affects the structure of aquatic lichen groups (zonal distribution, Santesson, 1939; Coste, 2010; Thüs et al., 2014). Gilbert (1996) showed that aquatic lichen species in England are found in the form of overlapping streaks connected with the duration and altitude of flooding. Four zones are distinguished for rivers: (1) submerged zone, (2) fluvial mesic zone, (3) fluvial xeric zone and (4) fluvial terrestrial zone (Gilbert and Giavarini, 1997). Coste (2010), examining the zonal distribution of epilithic freshwater lichens in France, distinguished three types: (1) hyper-hydrophilic lichens, (2) meso-hydrophilic lichens and (3) sub-hydrophilic lichens defined according to the duration of submersion, more than 9 months, between 6 and 9 months, and between 3 and 6 months, respectively. Except for permanently submerged species, freshwater lichens are exposed to fluctuations in light intensity and water availability, which can be extreme in time and space. Poikilohydric organisms, such as lichens, regularly dry out and gas 
exchange changes dramatically with thallus water content (Green et al., 1993). Thus, lichens can be exposed to high solar radiation in a desiccated state suggesting that their photosynthetic apparatus is exposed to damage. Exposure to (strong) light in the desiccated state has been shown to cause reduction in quantum efficiency (Gauslaa and Solhaug, 1996). In previous studies, it has often been assumed that wet and illuminated lichens are fully photosynthetically active and that photosynthetic activation in lichens occurs instantaneously (Coxson, 1988; Lange et al., 1989; Palmqvist and Sundberg, 2000; Dahlman and Palmqvist, 2003; Liden et al., 2010). However, a few publications report a lag time of several hours with suboptimal photosynthetic activity following liquid hydration of dry thalli (Lange et al., 1986). Compared with desiccation in darkness, desiccation in light aggravated the drying damage in chlorolichens, it prolonged the activation time lag, and reduced quantum efficiency (Gauslaa et al., 2012). For these lichens, activity does not accurately coincide with wet time and the chances for positive net production will decrease if hydration is broken into short events (Jonsson-Cabrajic et al., 2010). Persistence and growth of lichens are however dependent on positive net photosynthesis. Can this explain the confinement of freshwater species to habitats that provide sufficiently long hydration periods?

In this study, we wish to understand whether potential photosynthetic limitation related to activation/ inactivation time lags following liquid hydration/air dehydration could affect the zonal distribution of epilithic freshwater lichens. Moreover, the basic characteristics of freshwater lichen gas exchanges and photosystem II (PSII) activity were to be determined. To achieve this, laboratory $\mathrm{O}_{2}$ and $\mathrm{CO}_{2}$ gas exchanges in dry or water immerged or aerial fully hydrated thalli were analyzed in freshwater hyper, meso and sub-hydrophilic lichen species (Coste, 2010). In addition, analysis of chlorophyll (Chl) fluorescence, which gives information about the efficiency of PSII, was used to characterize species-specific patterns in photosynthesis activation after hydration and inactivation during desiccation (Lange et al., 1989; Green et al., 1993).

\section{Materials and methods}

\section{Lichen sampling and measurement of their dry and wet weight}

Freshwater lichens on siliceous rock were collected from their specific habitats (sun-exposed watercourses) in the south of France in August 2011. Half of the lichens were collected in the Massif Central, around the "Montagne Noire" (Mazamet, Gorges du Banquet, long. $2^{\circ} 28^{\prime} 39^{\prime \prime} \mathrm{E}$, lat. $\left.43^{\circ} 30^{\prime} 49^{\prime \prime} \mathrm{N}\right)$. The other half were collected in the sub-Mediterranean region "Languedoc" (Rosis, Rieutord, long. $2^{\circ} 58^{\prime} 11^{\prime \prime} \mathrm{E}$, lat. $\left.43^{\circ} 35^{\prime} 38^{\prime \prime} \mathrm{N}\right)$. Both regions are located in the hills stage (between 520 and $700 \mathrm{~m}$ a.s.l. with mean annual temperature of $10-11^{\circ} \mathrm{C}$ ) and in a damp locality (precipitations are around 1000 and
1400 mm.year ${ }^{-1}$ ). Rocks in both places are composed of "eyed" gneiss.

Freshwater lichens were distinguished according to three annual durations of submersion in the stream: hyper, meso and sub-hydrophilic lichens undergo more than 9 months, between 6 and 9 months, and between 3 and 6 months submersion, respectively (duration recorded over several years based on regular, i.e., at least monthly field visits, personal observations, Coste, 2010). The most common and abundant species in the different zones were sampled for subsequent laboratory experiments. The species selected for the present study were chlorolichens with a crustaceous thallus: Verrucaria funckii (Spreng.) Zahlbr. (noted VF), a hyperhydrophilous lichen covering $78 \%$ of the zone; Ionaspis lacustris (With.) Lutz. (noted IL) and Porpidia hydrophila (Fr.) Hertel and Schwab (noted PH), two mesohydrophilous lichens covering $65-89 \%$ of the zone; and Verrucaria praetermissa (Trevis.) Anzi (noted VP), a subhydrophilous lichen covering $85 \%$ of the zone. At the time of collection, all lichens were exposed to air (dry) and full sunlight. Living colonies were taken from stones with hammer and graver (lichens attached to the stones), placed in paper bags and transported in a glass box to the laboratory where they were stored in ambient air $\left(20 \pm 2{ }^{\circ} \mathrm{C}\right.$ and $50 \pm 5 \%$ relative humidity $R H$ ) in the dark. IL and $\mathrm{PH}$ mesohydrophilous lichens were not distinguished because they were generally found in the form of overlapping streaks. We thus consistently used mixed samples of these two species.

In the laboratory, the so-called "dry thalli" contained less than $5 \%$ water. Each sample corresponded to one piece of rock with intact lichen cover. The time course of water gain or loss was assessed by weighing the thalli (with the substratum) at 2 min intervals for rehydration in water from their watercourse (excess water was removed by gentle shaking before measurements) and at 5 min intervals to determine the rate of desiccation in ambient air in the dark $\left(20^{\circ} \mathrm{C}\right.$ and $\left.50 \% R H\right)$. At the end of the experiments, the thalli were dried for $48 \mathrm{~h}$ in an oven at $80^{\circ} \mathrm{C}$ and weighed. Then, the thalli were transformed into ash for $5 \mathrm{~h}$ at $450^{\circ} \mathrm{C}$. The ash was removed from the rock with a brush and weighed. Data allowed the dry, fresh and water saturated mass of the lichens to be calculated. The relative water content $(R W C)$ on a dry mass basis was calculated as ((fresh mass - dry mass)/(dry mass) $) \times 100$.

\section{Pigment analysis and ergosterol determination}

The samples were collected on August 14 and 15, 2011 between 10:00 and 13:00 $\mathrm{h}$ (temperature about $20^{\circ} \mathrm{C}$, humidity lower than $20 \%$ and photosyntheticallly active photon flux density (PPFD) about $1500 \mu \mathrm{mol} . \mathrm{m}^{-2} . \mathrm{s}^{-1}$ ) and transported in liquid nitrogen before storage in the laboratory at $-80{ }^{\circ} \mathrm{C}$. All samples showed less than $10 \%$ hydration. The identification and quantification of the photosynthetic pigments were carried out according to the method described by Barlow et al. (1997). The samples 
were harvested by scraping lichen thalli from the substratum and were then lyophilized. The pigments were extracted with methanol before analysis by highperformance liquid chromatography (HPLC).

Ergosterol, a membrane component largely restricted to eumycotic fungi, was used as a surrogate for mycelial biomass (Gessner and Chauvet, 1993). Extraction and analysis followed the procedure indicated in Gessner (2005). Ergosterol was extracted from dried portions of thalli $(38 \pm 2 \mathrm{mg})$ in $5 \mathrm{~mL}$ of $\mathrm{KOH} / \mathrm{methanol}\left(8 \mathrm{~g} . \mathrm{L}^{-1}\right)$ for $30 \mathrm{~min}$ at $80^{\circ} \mathrm{C}$. The extract was then purified by solid phase extraction (Waters Oasis HLB 3 cc cartridges; Waters Corp, Milford, MA) and quantified by HPLC pump 422, HPLC detector 432, HPLC autosampler 360 (Kontron Instruments, Neufahrn, Germany) by measuring absorbance at $282 \mathrm{~nm}$. The HPLC system was equipped with a FLT $0.5 \mu \mathrm{m}$ A-316 precolumn (Upchurch Scientific, Oak Harbour, WA) and a LispRP 18-5 $250 \times$ 4.6-mm column (Thermo-Hypersil Keystone, Bellefonte, PA) maintained at $33{ }^{\circ} \mathrm{C}$. The mobile phase was $100 \%$ methanol, and the flow rate was set to $1.4 \mathrm{~mL} \cdot \mathrm{min}^{-1}$.

\section{Respiration and photosynthesis}

Respiration and photosynthesis were measured either via $\mathrm{O}_{2}$ (under water) or $\mathrm{CO}_{2}$ (aerial) exchanges as stated in the section Results. These activities were measured on about $1 \mathrm{~cm}^{2}$ of the thalli with the substratum a few days after collection from the watercourse. Before measurements, samples were fully hydrated by immersion for $24 \mathrm{~h}$ in the stream water at $20^{\circ} \mathrm{C}$ and under a PPFD of $100 \mu \mathrm{mol} . \mathrm{m}^{-2} \cdot \mathrm{s}^{-1}$.

$\mathrm{O}_{2}$ exchange was measured on under-water samples enclosed in Plexiglas chambers with stirring, placed in a water bath at $15^{\circ} \mathrm{C}$ (Liden et al., 2010). Rates of $\mathrm{O}_{2}$ exchange were measured using oxygen microprobes in hermetically sealed chambers (Strath-Kelvin 928 System, North Lanarkshire, UK) and a PPFD of 0.80 and $200 \mu \mathrm{mol} . \mathrm{m}^{-2} \cdot \mathrm{s}^{-1}$ at the lichen level (type lamp: FHO 24W/T5 550 Osram Sylvania Ltd, Canada). Thalli were immerged in $5 \mathrm{~mL}$ filtered stream water $(0.2 \mu \mathrm{m}$ sterile cellulose membrane, Whatman International Ltd., Maidstone, UK) containing 0.07 g.L $\mathrm{L}^{-1} \mathrm{~K}_{2} \mathrm{CO}_{3}, \mathrm{pH} 6.8$.

$\mathrm{CO}_{2}$ exchanges were measured on aerial samples enclosed in $50 \mathrm{~mL}$ 'Venoject' tubes hermetically sealed and placed in the dark or under PPFD of $500 \mu \mathrm{mol} . \mathrm{m}^{-2} . \mathrm{s}^{-1}$ (type lamp: FHO 24W/T5 550 Osram Sylvania Ltd, Canada) or $2000 \mu \mathrm{mol} . \mathrm{m}^{-2} \cdot \mathrm{s}^{-1}$ (natural sunlight). Every $60 \mathrm{~min}, 1 \mathrm{~mL}$ of the air in the tube was taken using a syringe and injected into a Licor 830 gas analyzer (Li-Cor, USA) for determination of $\mathrm{CO}_{2}$ concentration.

Photosynthetic activity was also measured as the maximal (dark-adapted) quantum efficiency of PSII " $F_{\mathrm{v}} / F_{\mathrm{m}}$ " which is the ratio of the variable $\left(F_{\mathrm{v}}=F_{\mathrm{m}}-F_{\mathrm{o}}\right)$ to the maximal $\left(F_{\mathrm{m}}\right)$ Chl $a$ fluorescence measured by a Licor 6400. This activity was investigated in 24 -h dark hydrated thalli a few days after collection of the lichens from their watercourse or after 4 months storage at room temperature in the dark. To monitor lichen activation/deactivation patterns for the different species, photosynthetic activity (PSII) was recorded following dry thallus rehydration by liquid water and then following desiccation of $24 \mathrm{~h}$ fully hydrated thalli in-air with a water potential of $-100 \mathrm{MPa}$ $\left(50 \% R H\right.$ and $\left.20^{\circ} \mathrm{C}\right)$.

\section{Statistical analysis}

$F_{\mathrm{v}} / F_{\mathrm{m}}$ was obtained from an average of 5 pulses applied for each of 10 different thalli. All the results were variancetested and submitted to Tukey tests (with significant differences) with Statgraphics software Centurion XV.II. Different homogeneous groups are identified with letters on graphs: a, b, c, d $(P<0.001)$. Error bars show the standard error of replicates.

\section{Results}

\section{Biomass characteristics and pigment composition}

VP (Sub) and VF (Hyper) species displayed similar low (8 mg dry weight $(D W) . \mathrm{cm}^{-2}$ ) specific thallus mass (STM), whereas IL and PH (Meso) species had a 2-fold higher biomass. The pools of ergosterol and of the major photosynthetic pigments are described in Table 1 for the four species. VP (Sub) had the highest ergosterol concentration (1.4 mg.g $\mathrm{g}^{-1} D W$ ), while species IL and PH (Meso) and VF (Hyper) showed significantly lower concentrations (0.45 mg.g ${ }^{-1} D W$ ). The levels of chlorophyll $a$ and $b$, and pheophytin $a$ were the highest in lichen VP (Sub) as was ergosterol. Chla concentrations followed a similar pattern to ergosterol for the four lichen species but $\mathrm{Chl} b$ and pheophytina displayed different profiles. Pheophytin $a$ represented at most $7 \%$ of the amount of chlorophyll $a+b$. In all species, caroten, lutein and zeaxanthin were the most abundant carotenoids in the tissues. Violaxanthin was present in very small amounts compared with zeaxanthin (less than 1\%).

\section{Gas exchange}

Rates of steady-state dark respiration in freshwater lichens were measured through $\mathrm{O}_{2}$ uptake by thalli immersed in water or through $\mathrm{CO}_{2}$ production on fully hydrated thalli in-air. Both methods gave similar values in the range of $2-5 \mathrm{nmol.g} \mathrm{g}^{-1} \mathrm{DW} \cdot \mathrm{s}^{-1}$ (Fig. 1) corresponding to $0.2-0.5 \mu \mathrm{mol} . \mathrm{m}^{-2} . \mathrm{s}^{-1}$. Sub-hydrophilic lichen (VP) displayed significantly higher dark respiration than hyperhydrophilic (VF) species, while meso-hydrophilic (IL and $\mathrm{PH}$ ) species showed intermediate values. Dark respiration on dehydrated lichens in-air was undetectable (not shown).

For all species, photosynthetic activity estimated through the rate of $\mathrm{O}_{2}$ production by underwater thalli 
Table 1. Pigment and ergosterol concentrations in freshwater lichens distinguished according to their durations of submersion in streams. Lichens were collected in the dry state in full sunlight.

\begin{tabular}{|c|c|c|c|c|c|c|}
\hline \multirow[b]{2}{*}{ Units } & \multicolumn{2}{|c|}{ VP sub } & \multicolumn{2}{|c|}{ IL and PH meso } & \multicolumn{2}{|c|}{ VF hyper } \\
\hline & & & & $\mu \mathrm{g} . \mathrm{g}^{-}$ & & \\
\hline Ergosterol & $\mathrm{a}$ & $1394 \pm 54$ & $\mathrm{~b}$ & $431 \pm 53$ & $\mathrm{~b}$ & $467 \pm 17$ \\
\hline chlorophylla & $\mathrm{a}$ & $842 \pm 129.5$ & $b$ & $244 \pm 60$ & $\mathrm{~b}$ & $324 \pm 21.7$ \\
\hline chlorophyll $b$ & $\mathrm{a}$ & $91 \pm 15$ & $\mathrm{~b}$ & $29 \pm 7$ & $\mathrm{~b}$ & $56 \pm 41$ \\
\hline Pheophytin $a$ & $\mathrm{a}$ & $80 \pm 1.58$ & $b$ & $18 \pm 2$ & $\mathrm{~b}$ & $39 \pm 2.84$ \\
\hline$\beta$ caroten & $\mathrm{a}$ & $411 \pm 61$ & $\mathrm{~b}$ & $92 \pm 37$ & $\mathrm{~b}$ & $157 \pm 10.8$ \\
\hline Lutein & $\mathrm{a}$ & $145 \pm 18.9$ & $b$ & $44 \pm 10$ & $\mathrm{~b}$ & $64 \pm 45$ \\
\hline Zeaxanthin & $\mathrm{a}$ & $53.9 \pm 1.1$ & $\mathrm{~b}$ & $14.9 \pm 0.5$ & $\mathrm{~b}$ & $12.6 \pm 0.85$ \\
\hline Violaxanthin & $\mathrm{a}$ & $0.226 \pm 0.003$ & $\mathrm{~b}$ & $0.086 \pm 0.009$ & $\mathrm{~b}$ & $0.103 \pm 0.007$ \\
\hline
\end{tabular}

VP sub, Verrucaria praetermissa, subhydrophilic; IL and PH meso, Ionaspis lacustris and Porpidia hydrophila, mesohydrophilic; VF hyper, Verrucaria funckii, hyperhydrophilic.

Values are means $\pm \mathrm{SE} ; n=10$. The different letters correspond to statistically different groups $(P<0.001)$.

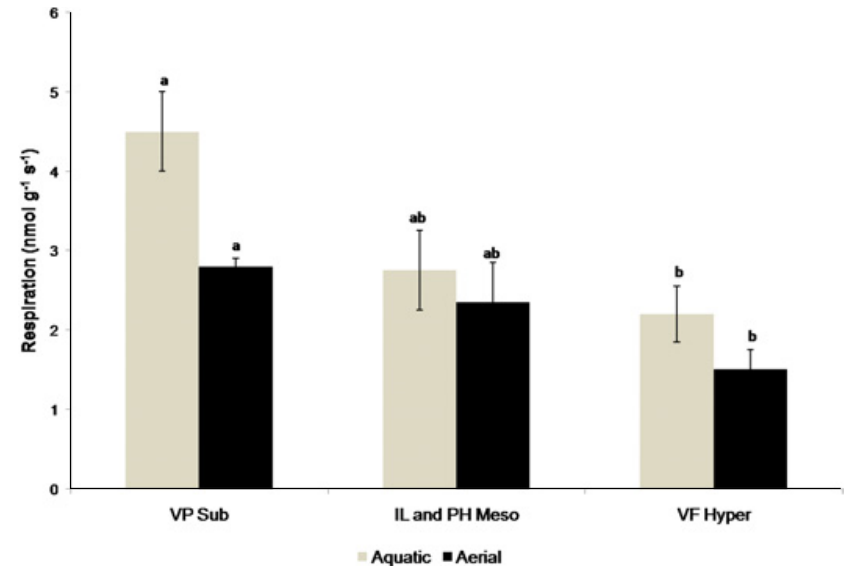

Fig. 1. Dry mass-related dark respiration of wet thalli of freshwater lichens. Respiration of immerged thalli $\left(\mathrm{O}_{2}\right.$ uptake $)$ or aerial fully hydrated thalli $\left(\mathrm{CO}_{2}\right.$ evolution) was measured on selected species. Experiments were performed a few days after collection of dry lichens from sun-exposed watercourses. Values are means $\pm \mathrm{SE} ; n=30$, the different letters correspond to statistically different groups $(P<0.001)$. Statistical analyses were performed separately for immerged or aerial thalli. VP sub, Verrucaria praetermissa subhydrophilic; IL and PH meso, Ionaspis lacustris and Porpidia hydrophila mesohydrophilic; VF hyper, Verrucaria funckii hyperhydrophilic.

was positive under a PPFD of $200 \mu \mathrm{mol} . \mathrm{m}^{-2} \cdot \mathrm{s}^{-1}$ (at lichen level, Fig. 2). Species VP (Sub) displayed the highest rate $\left(3.5 \mathrm{nmol} \mathrm{O}_{2} \cdot \mathrm{g}^{-1} \cdot \mathrm{s}^{-1}\right)$, whereas VF (Hyper) species showed the lowest activity $\left(0.1 \mathrm{nmol} \mathrm{O}_{2} \cdot \mathrm{g}^{-1} \cdot \mathrm{s}^{-1}\right)$. Under reduced PPFD (80 $\left.\mu \mathrm{mol} . \mathrm{m}^{-2} . \mathrm{s}^{-1}\right)$, only VP (Sub) lichen species showed positive (although strongly decreased) $\mathrm{O}_{2}$ evolution, while other species displayed slightly negative $\mathrm{O}_{2}$ evolution. $\mathrm{CO}_{2}$ uptake on dehydrated lichens in-air was undetectable (not shown). Aerial fully hydrated thalli exposed to PPFD of $500 \mu \mathrm{mol} . \mathrm{m}^{-2} . \mathrm{s}^{-1}$ revealed positive $\mathrm{CO}_{2}$ assimilation for all species (Fig. 2). VP (Sub) lichen presented the highest rate of $\mathrm{CO}_{2}$ assimilation as compared with other species. The order of magnitude of gas exchanges for immerged $\left(\mathrm{O}_{2}\right)$ or aerial $\left(\mathrm{CO}_{2}\right)$ samples was consistent. A very high PPFD (2000 $\left.\mu \mathrm{mol} . \mathrm{m}^{-2} . \mathrm{s}^{-1}\right)$ inhibited $\mathrm{CO}_{2}$ assimilation in fully hydrated aerial IL and PH (Meso) and VF (Hyper) lichens, which appeared to be negative. By contrast, VP (Sub) species showed enhanced rates of $\mathrm{CO}_{2}$ assimilation under high light intensity.

\section{PS II function of the hydrated and desiccated states, and after rehydration/dehydration cycle}

The maximal stable quantum efficiency of PSII photochemistry was investigated on $24 \mathrm{~h}$ hydrated lichens the day after they were collected from their habitat or after they were air-dried at room temperature in the dark for 4 months (Table 2). The maximum $F_{\mathrm{v}} / F_{\mathrm{m}}$ values differed among the species being the highest in VP (Sub) and the lowest in VF (Hyper). Four months spent in a desiccated state led to decreased $F_{\mathrm{v}} / F_{\mathrm{m}}$ in hyper and mesohydrophilic lichens but did not affect fluorescence yield in sub-hydrophilic plants.

Lichens with a water content of about $5 \%$ of their $D W$ (Fig. 3) did not show any variable fluorescence at room temperature (Fig. 4). When dry samples of all lichen species were rehydrated in the dark by wetting with liquid water, they became fully water saturated within 8 min (Fig. 3). More than $80 \%$ of the maximal $R W C$ was already reached after $2 \mathrm{~min}$. Maximal $D W$ related water content was the highest $(200 \%)$ in the hyper-hydrophilic lichen. An increase was noted in maximal variable fluorescence during this procedure (Fig. 4). All lichens regained near steady-state fluorescence in less than 6-7 min following immersion in liquid water (the value reached at $t=9 \mathrm{~min}$ was not enhanced by an additional $24 \mathrm{~h}$ hydration with water). However, slight differences between the species appeared in the recovery process. For VP (Sub), PSII activation was already $95 \%$ of the maximum value after the shortest interval tested, i.e., 1 min. In contrast, VF (Hyper) and IL and PH (Meso) exhibited slower activation, with only around $30-35 \%$ of steady state $F_{\mathrm{v}} / F_{\mathrm{m}}$ after $1 \mathrm{~min}$ and $95 \%$ after 3-4 min rehydration. Furthermore, the maximal $F_{\mathrm{v}} / F_{\mathrm{m}}$ values reached at $t=9 \mathrm{~min}$ by the species displayed the same ranking as that reported in Table 2: VP (0.60), IL and PH (0.44) and VF (0.31), in decreasing order. 


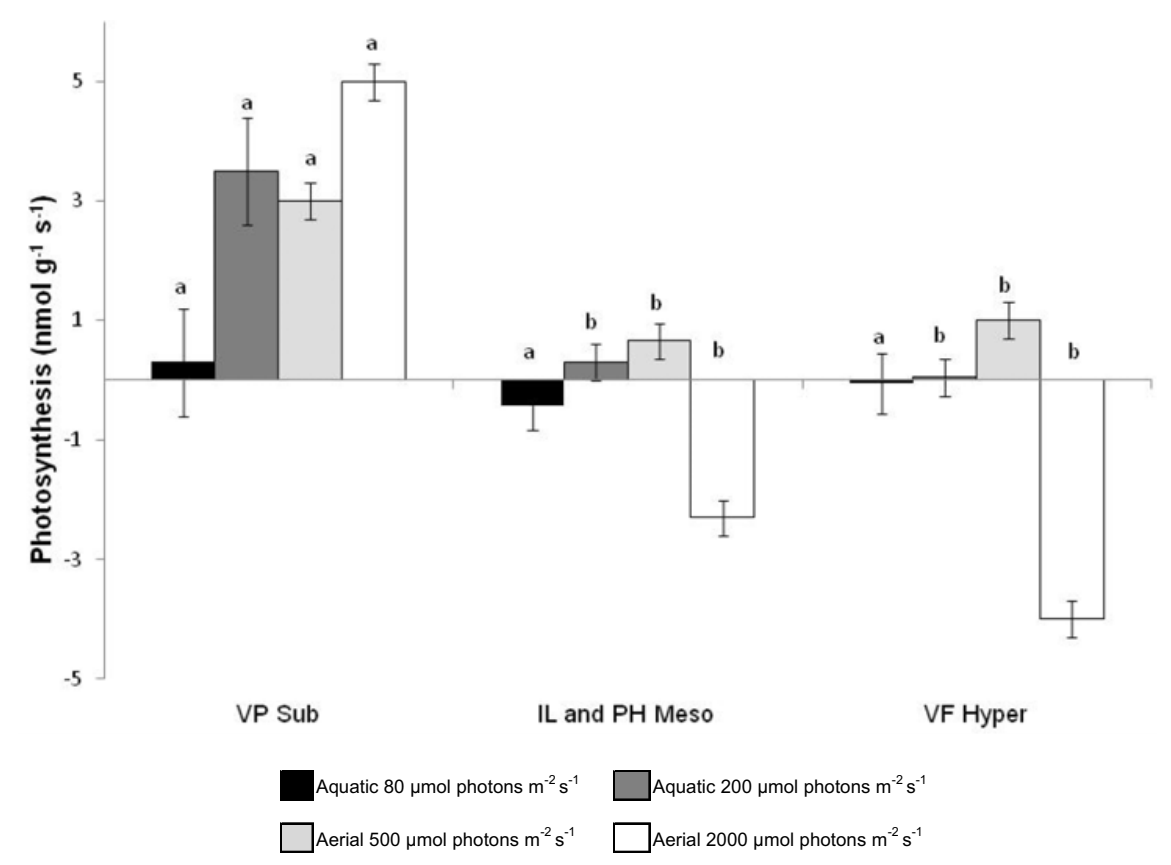

Fig. 2. Dry mass-related net photosynthesis of wet thalli of freshwater lichens. Photosynthesis of immerged thalli $\left(\mathrm{O}_{2}\right.$ evolution $)$ or aerial fully hydrated thalli $\left(\mathrm{CO}_{2}\right.$ uptake) were measured on selected species. Light irradiance at thallus level was $80 \mu \mathrm{mol} . \mathrm{m}^{-2} . \mathrm{s}^{-1} P A R$ (photosynthetically active radiation) or $200 \mu \mathrm{mol} . \mathrm{m}^{-2} \cdot \mathrm{s}^{-1} P A R$ for underwater measurements and $500 \mu \mathrm{mol} . \mathrm{m}^{-2} . \mathrm{s}^{-1} P A R$ or $2000 \mu \mathrm{mol} . \mathrm{m}^{-2} . \mathrm{s}^{-1} P A R$ for aerial measurements. Values are means $\pm \mathrm{SE} ; n=30$, the different letters correspond to statistically different groups $(P<0.001)$. Statistical analyses were performed separately for immerged or aerial thalli. Lichen species and sampling, see legend of Figure 1.

Table 2. Maximal quantum yield of PSII $\left(F_{\mathrm{v}} / F_{\mathrm{m}}\right)$ in 24 h-hydrated freshwater lichens after 1 day or after 4 months air dry dark storage at room temperature following collection from the watercourse.

\begin{tabular}{llcc}
\hline & & Duration in the dry state after sampling before 24 h-rehydration \\
\cline { 2 - 3 } & & 1 day & 4 months \\
\hline Verrucaria praetermissa (VP) Sub & $\mathrm{a}$ & $0.64 \pm 0.01$ & $0.66 \pm 0.01$ \\
$\begin{array}{l}\text { Ionaspis lacustris and Porpidia hydrophila } \\
\text { (IL and PH) Meso }\end{array}$ & $\mathrm{ab}^{*}$ & $0.59 \pm 0.01$ & $0.53 \pm 0.02$ \\
Verrucaria funckii (VF) Hyper & $\mathrm{b}^{*}$ & $0.42 \pm 0.03$ & $0.33 \pm 0.07$ \\
\hline
\end{tabular}

Means $\pm \mathrm{SE} ; \mathrm{n}=10$. The different letters correspond to statistically different groups $(\mathrm{P}<0.001)$. The $*$ correspond to statistical tests performed on the same species at day 0 and 4 months $(\mathrm{P}<0.01)$.

$R W C$ and the fluorescence yield were then investigated during dehydration in-air $\left(20^{\circ} \mathrm{C}\right.$ with $\left.50 \pm 5 \% R H\right)$ of the fully hydrated lichens. The species-specific desiccation time-series presented in Figure 3 revealed that lichens lost about $50 \%$ of their water every $5 \mathrm{~min} . F_{\mathrm{v}} / F_{\mathrm{m}}$ was also very sensitive to desiccation (Fig. 4). Cessation of photosystem activity, indicated by an $F_{\mathrm{v}} / F_{\mathrm{m}}$ value below 0.1 (Liden et al., 2010) was reached after $15 \mathrm{~min}$ in-air for $\mathrm{VF}$ (Hyper), whereas it took longer for IL and PH (Meso) or VP (Sub) species corresponding to a water content of about 20 and $15 \%$ of their $D W$, respectively.

\section{Discussion}

Ergosterol is the major sterol of the fungal plasma membrane and is used as an indicator of the relative proportions of metabolically active fungal cells in lichens (Sundberg et al., 1999), while Chla may serve as a marker of total photobiont cells (Descy and Metens, 1996; Palmqvist et al., 1998). In freshwater lichens, the Chla to ergosterol ratio was similar in the four species investigated (around 0.6, Table 1). Values for Chl $a, b$ and ergosterol in freshwater lichens were in the range of those previously found for non-aquatic lichens (Demmig-Adams et al., 1990; Sundberg et al., 1999).

STM appeared small compared with most non-aquatic lichens (Palmqvist et al., 1997, 1998, 2002) but some forest species have even lower values (Esseen et al., 2015). Because changes in STM of freshwater lichens were associated with opposite and proportional changes in Chl $a+$ ergosterol concentrations in the tissues, living STM (photobiont + mycobiont) was similar in the various freshwater lichens. Indeed, microscopic observations showed that dead biomass was more abundant in IL and PH (Meso) than in other species (not shown).

Rate of dark respiration in well watered freshwater lichens $\left(2-5 \mathrm{nmol} . \mathrm{g}^{-1} . \mathrm{s}^{-1}\right.$ and $\left.0.2-0.5 \mu \mathrm{mol} . \mathrm{m}^{-2} . \mathrm{s}^{-1}\right)$ was 


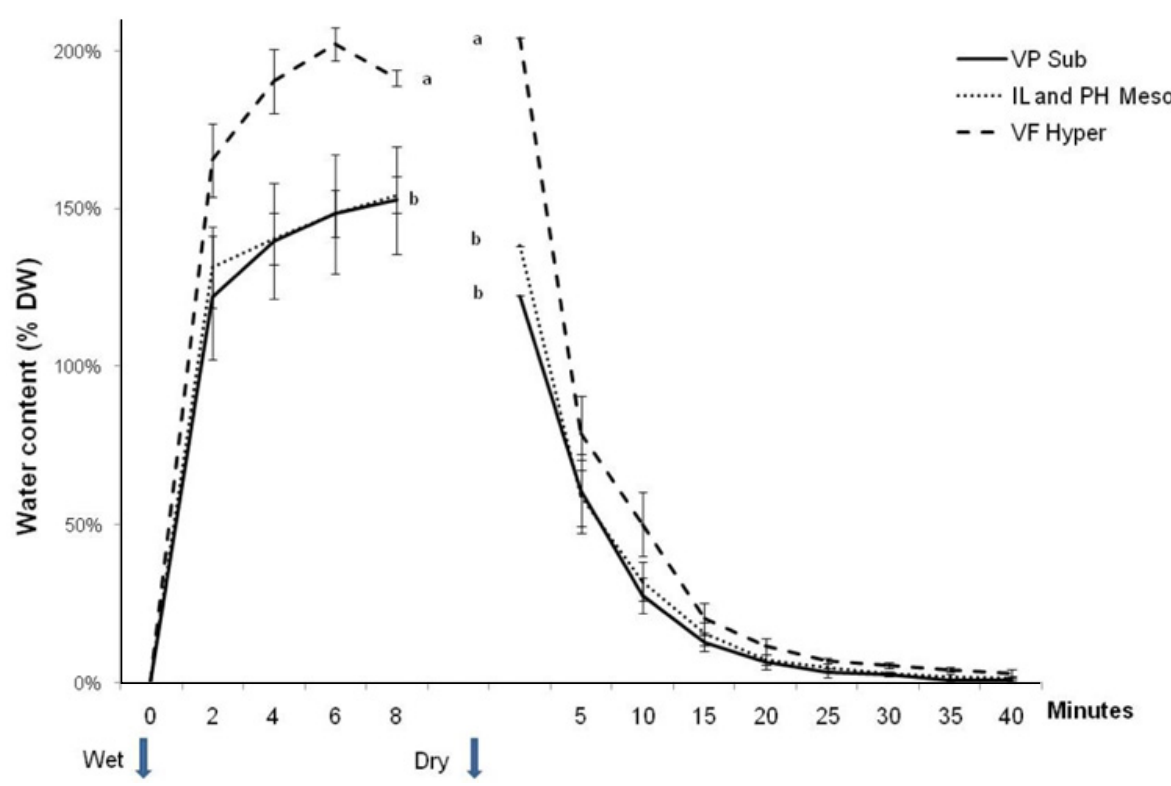

Fig. 3. Changes in lichen freshwater water content versus time after immersion in liquid water of dry thalli and then after placing the hydrated thalli in-air (at $T=20^{\circ} \mathrm{C}$ and $R H=50 \%$ ). Values are means \pm SE; $n=10$, the different letters correspond to statistically different groups $(P<0.001)$. Lichen species and sampling, see legend of Figure 1. RH, relative humidity.

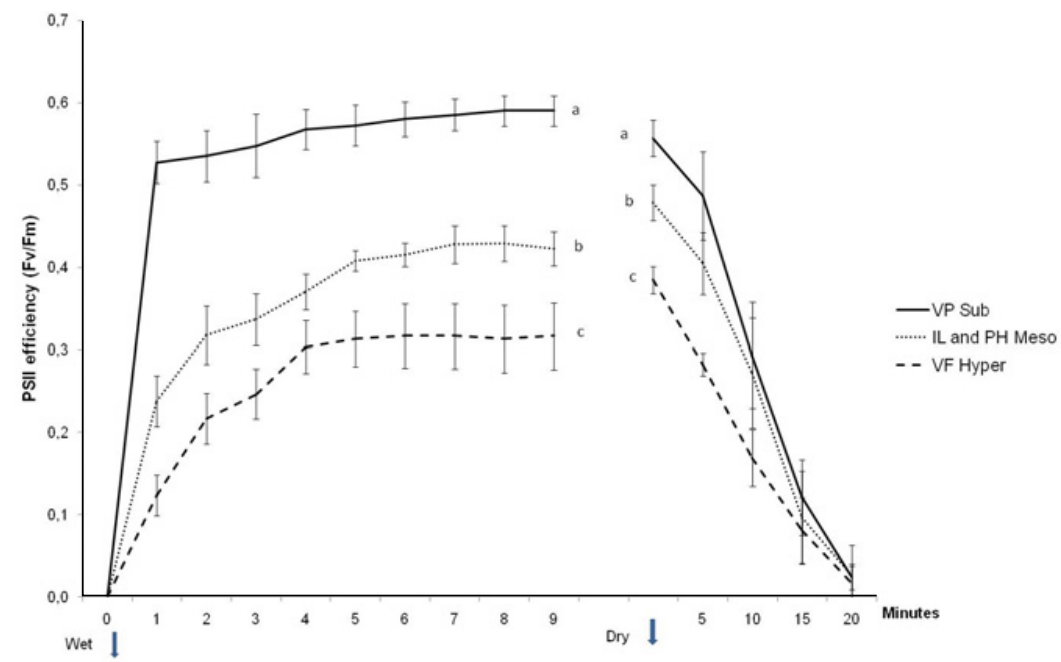

Fig. 4. Recovery of photosynthetic activity $\left(F_{\mathrm{v}} / F_{\mathrm{m}}\right)$ after hydration of dry freshwater lichen thalli by liquid water and then cessation of activity of fully hydrated fragments during dessication in-air (at $T=20^{\circ} \mathrm{C}$ and $R H=50 \%$ ). Values are means $\pm \mathrm{SE}$; $n=10$, the different letters correspond to statistically different groups $(P<0.001)$. Lichen species and sampling, see legend of Figure 1 . RH, relative humidity.

in the range of that reported by Lange et al. (1993a, 1993b, 2006) and Sundberg et al. (1999), but an order of magnitude lower than that in other studies (Lange et al., 1997) for non-aquatic lichens. Dark metabolic activity in sub-hydrophilic lichen was clearly higher than in hyperhydrophilic species.

Under low PPFD (immerged samples, $80 \mu \mathrm{mol} . \mathrm{m}^{-2} \cdot \mathrm{s}^{-1}$ ), net $\mathrm{O}_{2}$ evolution was close to zero, indicating that this PPFD is near the light compensating point. In a survey of lichens covering a range of habitats in New Zealand, saturation PPFD was measured from 82 to $766 \mu \mathrm{mol} . \mathrm{m}^{-2} \cdot \mathrm{s}^{-1}$ and light compensation point from 4 to $136 \mu \mathrm{mol} . \mathrm{m}^{-2} . \mathrm{s}^{-1}$ (Green et al., 1997).
Under moderate PPFD $\left(200 \mu \mathrm{mol} . \mathrm{m}^{-2} \cdot \mathrm{s}^{-1}\right.$ for immerged samples and $500 \mu \mathrm{mol} . \mathrm{m}^{-2} \cdot \mathrm{s}^{-1}$ for wet lichens in-air), $\mathrm{O}_{2}$ evolution and $\mathrm{CO}_{2}$ fixation were positive for all lichen species. Maximal rates of photosynthetic $\mathrm{O}_{2}$ evolution and $\mathrm{CO}_{2}$ fixation $\left(3-5 \mathrm{nmol} . \mathrm{g}^{-1} \cdot \mathrm{s}^{-1}\right.$ and $0.25-0.4 \mu \mathrm{mol} . \mathrm{m}^{-2} . \mathrm{s}^{-1}$ ) were in the low range of data for non-aquatic species reported by Demmig-Adams et al. (1990), Lange et al. (1993a, 1993b, 2006), but were much lower (more than 10-fold lower) than data of Lange et al. (1997, 2003), Lange (2003), and Green and Lange (1995). Freshwater lichens appeared to have a photosynthetic activity in the lower range of that of non-aquatic lichens. Many slow-growing lichens have low maximal 
photosynthetic rates; this is especially the case when photosynthesis is related to thallus area (and not Chl content) because of their low biomass-to-area ratio.

Under high PPFD $\left(2000 \mu \mathrm{mol} . \mathrm{m}^{-2} \cdot \mathrm{s}^{-1}\right.$, aerial thalli), $\mathrm{CO}_{2}$ assimilation was notably increased in VP (Sub) lichens, whereas it became dramatically negative in VF (Hyper) and IL and PH (Meso) species. Hyper-hydrophilic lichens, growing closer to the stream, are less exposed to direct sunlight than sub-hydrophilic species. Shadeadapted plants can photosynthesize positively at low light levels, whereas they display lower rates of photosynthesis under high irradiances (Loach, 1967). The sensitivity of hyper-hydrophilic lichens to high PPFD is thus consistent with their less sunny microhabitat.

The thalli studied here underwent periods of desiccation under natural light in their habitat with potential photoinhibitory effects, which require a long period to relax (Gauslaa et al., 2012). Lichen performance was characterized on $24 \mathrm{~h}$-hydrated thalli. This duration may not be sufficient to allow complete recovery from photoinhibition but our study reveals the metabolic abilities of freshwater lichens collected in summer when not submerged by the water of the stream.

In the dehydrated state, no photosynthetic $\mathrm{CO}_{2}$ assimilation occurred and therefore no photosynthetic energy consumption occurred. Simultaneously, Chl fluorescence (photon yield of photosynthesis) was extremely low in all freshwater lichens. The decrease in the photon yield of photosynthesis could either be due to "damage" to the PSII or to a "protective" process in the form of harmless energy dissipation (Demmig-Adams et al., 1990). The absence of variable fluorescence in the dry freshwater lichens studied was caused by a dramatic reduction in $F_{\mathrm{m}}$ (not shown). This indicates a pronounced increase in harmless thermal dissipation as reported by Demmig-Adams et al. (1990) in green algal lichen. Dry freshwater lichens had the typical complement of carotenoids present in green algae and higher plants ( $\beta$ carotene, lutein, violaxanthin and zeaxanthin (Demmig-Adams et al., 1990). In the thalli studied (dry and sun-exposed, sampled in August around midday), a considerable portion of the violaxanthin + zeaxanthin pool appeared to be under the form of zeaxanthin. This finding is consistent with the functioning of the xanthophyll cycle in lichens but does not prove that zeaxanthin is necessary for photoprotective dissipation of excessive energy. In fact, zeaxanthin apparently did not contribute to photoprotection of desiccation in the light in the green algal lichen Lobaria pulmonaria (Heber et al., 2000).

The present study reports the photosynthetic behavior of freshwater lichens sampled around midday in a dry state in summer. When the species were rehydrated in the dark, they all exhibited rapid activation of PSII, which reached a near steady-state value in less than $7 \mathrm{~min}$. This may allow freshwater lichens to exploit brief hydration events (Liden et al., 2010). Values of 0.4-0.6 for maximal efficiency of PSII following $24 \mathrm{~h}$ rehydration of the dry thalli (Table 1) are probably below the real maximal efficiency. Lichens may have been photoinhibited in the dry state under natural light and relaxation of photoinhibition when moistened can take longer than $24 \mathrm{~h}$ (Gauslaa et al., 2012). The lichens studied underwent unknown periods of aerial (drying) events in their watercourse before sampling. Light exposure during drying could be highly detrimental. However, chlorolichens do not need liquid water to restore photosynthesis (Lange et al., 1986). Hydration of in-air freshwater lichen thalli in their watercourse with cool and humid nights could allow regular photosynthetic activation in summer.

Comparing sub- and hyper-hydrophilic species, VF (hyper-hydrophilic) had the highest maximal $R W C$ and the lowest metabolic (rates of dark respiration and photosynthesis) and photochemical performance in the wetted state, displayed negative photosynthesis under high irradiance, took more time for PSII activation to reach near steady-state values after rehydration but less time to deactivate following exposure to air, and displayed lowered PSII photochemistry following a long period of dehydration. These differences are consistent with the duration of submersion undergone by the lichen in its natural environment and may partly explain habitat distribution patterns of the sub- versus the hyper-hydrophilic species. The present differences between sub- and hyper-hydrophilic freshwater lichens were smaller than those of species-specific patterns of PSII activation timelags and water-holding capacity which allowed Liden $e t$ al. (2010) to explain habitat restriction. However, following Jonsson-Cabrajic et al. (2010), we consider that slightly slower activation (6 min against $1 \mathrm{~min})$ and higher sensitivity of PSII to desiccation may be important factors to explain the confinement of the most freshwater-related species to habitats that provide sufficiently long hydration periods. Indeed, small differences in activation/deactivation time-lag could strongly affect the lichen's long-term performance if hydration/desiccation events are brief and frequent.

Acknowledgements. We would like to warmly thank E. BufanDubau, S. Lamothe, D. Lambrigot (Ecolab) and P. Maury (ENSAT) for their precious technical help.

\section{References}

Aptroop A. and Seaward M.R.D., 2003. Freshwater lichens. Fungal Diversity Res., 10, 101-110.

Barlow R.G., Cummings D.G. and Gibb S.W., 1997. Improved resolution of mono and divinyl chlorophylls a and b and zeaxanthine and luteine in phytoplancton extracts using reverve phase C-8 HPLC. Mar. Ecol. Prog. Ser., 161, 303-307.

Coste C., 2010. New ecology and new classification for phytosociology of hydrophilic lichens in acid watercourses in France. Acte du colloque des 3 èmes rencontres Naturalistes de Midi-Pyrénées, 157-168.

Coxson D.S., 1988. Recovery of net photosynthesis and dark respiration on rehydration of the lichen, Cladina mitis, and the influence of prior exposure to sulphur dioxide while desiccated. New Phytol., 108, 483-487. 
Dahlman L. and Palmqvist K., 2003. Growth in two foliose tripartite lichens, Nephroma arcticum and Peltigera aphthosa: empirical modelling of external vs internal factors. Funct. Ecol., 17, 821-831.

Demmig-Adams B., Adams W.W., Green T.G.A., Czygan F.-C. and Lange O.L., 1990. Differences in the susceptibility to light stress in two lichens forming a phycosymbiodeme, one partner possessing and one lacking the xanthophyll cycle. Oecologia, 84, 451-456.

Descy J.P. and Metens A., 1996. Biomass-pigment relationships in potamoplankton. J. Plankton Res., 18, 1557-1566.

Esseen P.-A., Olsson T., Coxson D. and Gauslaa Y., 2015. Morphology influences water storage in hair lichens from boreal forest canopies. Fungal Ecol., 18, 26-35.

Gauslaa Y. and Solhaug K.A., 1996. Differences in the susceptibility to light stress between epiphytic of ancient and young boreal forest. Funct. Ecol., 10, 344-354.

Gauslaa Y., Coxson D.S. and Solhaug K.A., 2012. The paradox of higher light tolerance during desiccation in rare old forest cyanolichens than in more widespread co-occurring chloroand cephalolichens. New Phytol., 195, 812-822.

Gessner M.O., 2005. Ergosterol as a measure of fungal biomass. In: Graça M.A.S., Bärlocher F. and Gessner M.O. (eds.), Methods to Study Litter Decomposition, Springer Verlag, Dordretch, The Netherlands, 189-195.

Gessner M.O. and Chauvet E., 1993. Ergosterol to biomass conversion factors for aquatic hyphomycetes. Appl. Environ. Microbiol., 59, 502-507.

Gilbert O., 1996. The lichen vegetation of chalk and limestone streams in Britain. Lichenologist, 28, 145-159.

Gilbert O. and Giavarini V., 1997. The lichen vegetation of acid watercourses in England. Lichenologist, 29, 347-367.

Green T.G.A. and Lange O.L., 1995. Photosynthesys in poikilohydric plants: a comparaison of lichens and bryophytes. In: Schulze E.DW. and Caldwell M.M. (eds.), Ecophysiology of Phytosynthesis, Springer Verla, Berlin, 319-341.

Green T.G.A., Budel B., Heber U., Meyer A., Zellner H. and Lange O.L., 1993. Differences in photosynthetic performance between cyanobacterial and green algal components of lichen photosymbiodemes measured in the field. New Phytol., 125, 723-731.

Green T.G.A., Büdel B., Meyer A., Zellner H. and Lange O.L., 1997. Temperate rainforest lichens in New Zealand: light response of photosynthesis. N. Z. J. Bot., 35, 493-504.

Heber U., Bilger W., Bligny R. and Lange O.L., 2000. Phototolerances of lichens, mosses and higher plants in an Alpine Environment: analysis of photoreactions. Planta, 211, 770-780.

Jonsson-Cabrajic A.V., Liden M., Lundmark T., OttossonLöfvenius M. and Palmqvist K., 2010. Modelling hydratation and photosystem II activation in relation to in situ rain and humidity patterns: a tool to compare performance of rare and generalist epiphytic lichens. Plant Cell Environ., 33, $840-850$.

Lange O.L., 2003. Photosynthetic productivity of the epilithic lichen: Lecanora muralis: long-term field monitoring of $\mathrm{CO}_{2}$ exchange and its physiological interpretation: III. Diel, seasonal, and annual carbon budgets. Flora, 198, 277-292.

Lange O.L., Kilian E. and Ziegler H., 1986. Water vapor uptake and photosynthesis of lichens: performance differences in species with green and blue-green algae as phycobionts. Oecologia, 71, 104-110.
Lange O.L., Bilger W., Rimke S. and Schreiber U., 1989. Chlorophyll fluorescence of lichens containing green and blue-green algae during hydration by water vapor uptake and by addition of liquid water. Bot. Acta, 102, 306-313.

Lange O.L., Büdel B., Meyer A. and Killian E., 1993a. Further evidence that activation of net photosynthesis by dry cyanobacterial lichens requires liquid water. Lichenologist, $25,175-189$.

Lange O.L., Büdel B., Heber U., Meyer A., Zellner H. and Green T.G.A., 1993b. Temperate rainforest lichens in New Zealand: high thallus water content can severely limit photosynthetic $\mathrm{CO}_{2}$ exchange. Oecologia, 95, 303-313.

Lange O.L., Belnap J., Reichenberger H. and Meyer A., 1997. Photosynthesis of green algal soil crust lichens from arid lands in southern Utah, USA: role of water content on light and temperature responses of $\mathrm{CO}_{2}$ exchange. Flora, 1 , $1-15$.

Lange O.L., Allan Green T.G., Melzer B., Meyer A. and Zellner H., 2006. Water relations and $\mathrm{CO}_{2}$ exchange of the terrestrial lichen Teloschistes capensis in the Namib fog desert: Measurements during two seasons in the field and under controlled conditions. Flora, 201, 268-280.

Liden M., Jonsson Cabrajic A.V., Ottosson-Löfvenius M., Palmqvist K. and Lundmark T., 2010. Species-specific activation times-lags can explain habitat restrictions in hydrophilic lichens. Plant Cell Environ., 33, 851-862.

Loach K., 1967. Shade tolerrance in tree seedlings 1. Leaf photosynthesis and respiration in plants raised under artificial shade. New Phytolol., 66, 607-621.

Nascimbene J. and Nimis P.L., 2006. Freshwater lichens of the Italian Alps: a review. Ann. Limnol. - Int. J. Lim., 42, 27-32.

Palmqvist K. and Sundberg B., 2000. Light use efficiency of dry matter gain in five macrolichens: relative impact of microclimate conditions and species specific traits. Plant Cell Environ., 23, 1-14.

Palmqvist K., De Los Rios A., Ascaso C. and Samuelson G., 1997. Phtosynthetic carbon acquisition in the lichens photobionts Coccomyxa and Trebouxia (Chlorophyta). Physiol. Plant., 101, 67-76.

Palmqvist K., Campbell D., Ekblad A. and Johansson H., 1998. Photosynthetic capacity in relation to nitrogen content and its partitioning in lichens with different photobionts. Plant Cell Environ., 21, 361-372.

Palmqvist K., Dahlman L., Valladares F., Tehler A., Sancho L.G. and Mattsson J., 2002. $\mathrm{CO}_{2}$ exchange and thallus nitrogen across 75 contrasting lichen associations from different climate zones. Oecologia, 133, 295-306.

Richardson D.H.S., 1993. The physiology of drying and rewetting in lichens. In: Jennings D.H. (ed.), A Stress Tolerance of Fungi, University of Liverpool, Mycology series, USA, 275-296.

Santesson R., 1939. Über der Zonationverhältnisse der Lacustrinen Flechten einiger Seen in Anebodegebeit. Medd. Lunds. Limnel. Inst., Lund, 1, 1-70.

Sundberg B., Ekblad A., Näsholm T. and Palmqvist K., 1999. Lichen respiration in relation to active time, temperature, nitrogen and ergosterol concentrations. Funct. Ecol., 13, 119-125.

Thüs H., Aptroot A. and Seaward M.R.D., 2014. Freshwater Fungi. In: Gareth Jones E.B., Hyde K.D. and Pang K-L. (eds.), De Gruyter, Berlin, 333-358. 